\title{
MARINE RADIOCARBON RESERVOIR EFFECT IN SOUTHERN ATLANTIC IBERIAN COAST
}

\author{
José M Matos Martins ${ }^{1,2} \cdot$ António M Monge Soares ${ }^{1}$
}

ABSTRACT. Research concerning the variability of the marine radiocarbon reservoir effect $(\Delta R)$ in the southern Iberian Atlantic coast confirms the existence of different $\Delta \mathrm{R}$ values for regions that correspond to different oceanographic conditions. Due to these oceanographic conditions, the southern Iberian Atlantic coast can be divided into 3 zones: the Barlavento (windward), where the coastal waters are influenced by an intense upwelling of the northeastern Atlantic circulation (positive $\Delta R$ values); the Sotavento (leeward), where an upwelling area of minor intensity occurs; and the Andalusian coast, where because of its configuration does not present any wind-driven coastal upwelling (negative $\Delta \mathrm{R}$ values). For the first time, $\Delta \mathrm{R}$ values were determined for the Sotavento coastal region and, at the same time, new $\Delta \mathrm{R}$ values were calculated for the Barlavento and the Andalusian coast for the last $3000 \mathrm{yr}$ taking into account the data already obtained but now using a new methodology for calculation. In this way, $\Delta \mathrm{R}$ weighted mean values were determined for the 3 regions of the southern Iberian Atlantic coast: $\Delta \mathrm{R}=+69 \pm 17{ }^{14} \mathrm{C}$ yr (Barlavento), $\Delta \mathrm{R}=-26 \pm 14{ }^{14} \mathrm{C}$ yr (Sotavento), and $\Delta \mathrm{R}=-108 \pm 31{ }^{14} \mathrm{C}$ yr (Andalusian coast). These values are in accordance with the different oceanographic conditions prevailing in these coastal regions. The data also allow identification of a Bond event at $0.8 \mathrm{ka}$ cal BP and a drastic change in the oceanographic conditions in the Barlavento and Andalusian coastal areas during the 5 th millennium cal BP.

\section{INTRODUCTION}

The marine radiocarbon reservoir effect $(\Delta \mathrm{R})$, defined as the difference between the reservoir age of the mixed layer of the regional ocean and the reservoir age of the mixed layer of the average world ocean in AD 1950 (Stuiver et al. 1986), is often determined for a particular geographical region by ${ }^{14} \mathrm{C}$ dating pairs of samples of the same age but of different origin (terrestrial and marine). Although reservoir ages are time-dependent, $\Delta \mathrm{R}$ is not. Nevertheless, complications can occur when rates of regional upwelling vary (Stuiver and Braziunas 1993:155). Since the intensity of ${ }^{14} \mathrm{C}$ depletion in the mixed layer depends upon the strength of wind-driven coastal upwelling and its rate is not constant but varies with time, it is likely that $\Delta \mathrm{R}$ values can vary in the course of time in those regions (Kennett et al. 1997; Ingram 1998; Ascough et al. 2005; Soares 2005; Soares and Dias 2006a, 2007; Martins et al. 2012). High positive $\Delta \mathrm{R}$ values can be correlated with a strong upwelling, while low or negative $\Delta \mathrm{R}$ values correspond with a weak, or even nonexistent, upwelling. As a measure of the regional enhancement or depletion of ${ }^{14} \mathrm{C}, \Delta \mathrm{R}$ can also be used as an upwelling proxy providing a significant direct signal of upwelling activity (Diffenbaugh et al. 2003).

Previous research concerning the variability of $\Delta \mathrm{R}$ in coastal waters off Atlantic Iberia (Soares 1989, 1993, 2005, 2010; Soares and Dias 2006a,b, 2007; Soares and Martins 2009, 2010) allowed the quantification of $\Delta \mathrm{R}$, which is of crucial importance for the correct calibration of ${ }^{14} \mathrm{C}$ ages of marine samples. Moreover, the results have shown a good correlation between $\Delta \mathrm{R}$ values and the oceanographic conditions present in the corresponding regions.

The western part of the southern Iberian Atlantic coast, the so-called Barlavento (windward) region, located between Cape San Vicente and Cape Santa Maria (Figure 1), is influenced by the dynamic effect of Cape San Vicente that allows upwelled water present along the western Portuguese coast to move southeastward and eastward, creating a quasi-permanent upwelling area around the cape

\footnotetext{
${ }^{1}$ Laboratório de Radiocarbono, Campus Tecnológico e Nuclear, Instituto Superior Técnico, Universidade Técnica de Lisboa, Estrada Nacional 10, ao km 139,7, 2695-066 Bobadela LRS, Portugal.

${ }^{2}$ Faculdade de Ciências e Tecnologia, CIMA, Universidade do Algarve Campus de Gambelas, 8005-139 Faro, Portugal. Corresponding author. Email: jmartins@ctn.ist.utl.pt.
} 
(Fiúza 1982, 1983; Fiúza et al. 1982; Ferreira 1984). A $\Delta \mathrm{R}$ weighted mean value of $+65 \pm 20{ }^{14} \mathrm{C}$ yr was determined in previous research for this coastal region, which is consistent with the prevailing oceanographic conditions (Soares and Martins 2009, 2010).

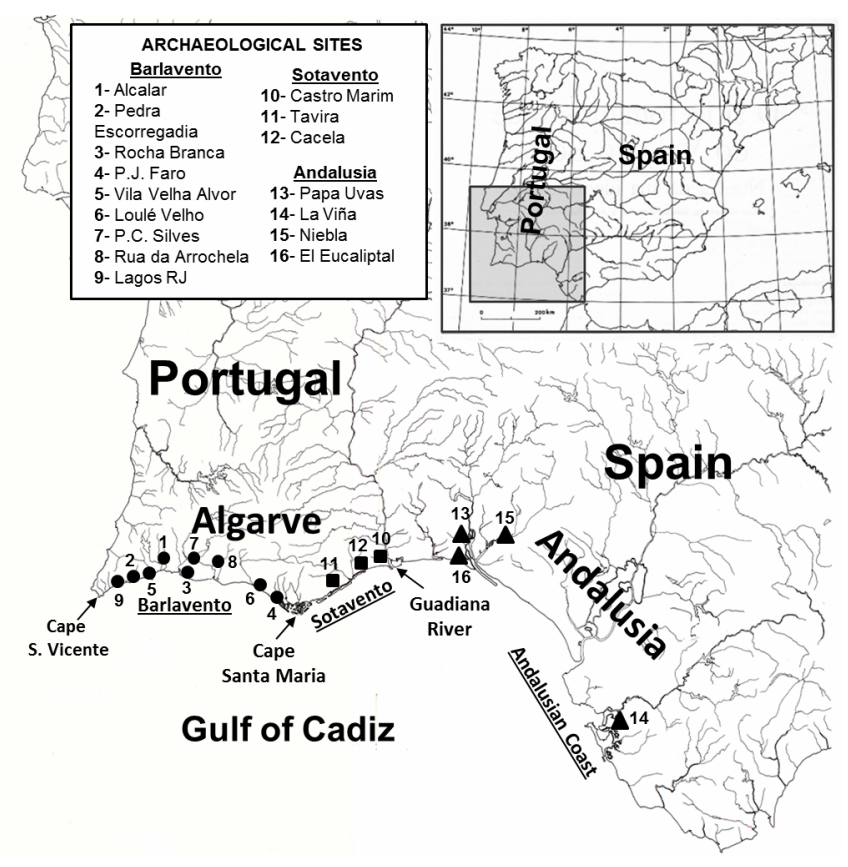

Figure 1 Location of coastal areas and archaeological sites analyzed herein

The central part of the southern Iberian Atlantic coast, the so-called Sotavento (leeward) region, located between Cape Santa Maria and the mouth of the Guadiana River (Figure 1), has not been analyzed in previous research concerning the variability of $\Delta \mathrm{R}$. In this region, when the prevailing winds in the Gulf of Cadiz are from the west, a minor upwelling area occurs offshore to the east of the cape (Vargas et al. 2003).

Finally, in the eastern part of the southern Iberian Atlantic coast (the Andalusian coast), due to its configuration (Figure 1) the wind-driven coastal upwelling is nonexistent. A $\Delta \mathrm{R}$ weighted mean value of $-135 \pm 20{ }^{14} \mathrm{C}$ yr was determined in previous research, which is consistent with a nonexistent coastal upwelling, suggesting some stratification of the water column (Soares and Martins 2009, 2010). Thus, the Sotavento coastal region can be considered a transition zone between an area where upwelled waters are important due to the influence of the western coastal upwelling system and an area where the upwelling regime is absent.

The aim of this work is the quantification, for the first time, of $\Delta \mathrm{R}$ for the Sotavento coastal region and the establishment of possible correlations between the $\Delta \mathrm{R}$ values and the oceanographic conditions present in this region. A different methodology from that one applied in previous research was used in the calculation of the $\Delta \mathrm{R}$ weighted mean values for the Barlavento and Andalusian coast, in order to corroborate and continue the previous research developed in this area of the southern Iberian Atlantic coast. 


\section{SAMPLING}

Pairs of closely associated archaeological samples (marine shells/charred wood or bones) from each depositional context were collected from archaeological sites present in the Sotavento region (see Figure 1). Samples come from kitchen refuse thought to have accumulated rapidly. Due to the close proximity of the samples forming each pair, it is assumed that the deposition of both types of samples (terrestrial and marine) was simultaneous or, in other words, that the time of death of the organisms from both reservoirs was the same.

For charred wood samples collected at the Castro Marim and Tavira archaeological sites, it was possible to undertake an anthracological analysis prior to dating (see Table 1). Nevertheless, since the measurement of the sample activity was made using a conventional liquid scintillation counting (LSC), we need samples with a weight of several grams, which led to the use, with an exception, of long-lived vegetal remains instead of short-lived species. Whenever possible and in order to overcome this problem, we used bone samples from the same archaeological context, namely from Tavira (see Table 1). Also, a sample of long-lived vegetal species associated with an Erica arborea sample was dated for the same purpose.

Concerning the shell samples, we tried whenever possible to date different shell species in order to test not only if their respective ${ }^{14} \mathrm{C}$ dating results were influenced by dietary or habit preferences, but also to identify eventual outliers.

\section{EXPERIMENTAL AND DATA PROCESSING}

Analytical procedures are described in detail elsewhere (Soares 2005; Soares and Dias 2006a, 2007). ${ }^{14} \mathrm{C}$ ages were calculated in accordance with the definitions recommended by Stuiver and Polach (1977). $\Delta \mathrm{R}$ values were calculated by converting the terrestrial biosphere sample ${ }^{14} \mathrm{C}$ age into a marine model age. This marine model age was then subtracted from the ${ }^{14} \mathrm{C}$ age of the associated marine shell sample to yield $\Delta \mathrm{R}$ (Stuiver and Braziunas 1993; Reimer et al. 2002).

We used a methodology based on Ascough et al. (2005, 2007, 2009) and Russell et al. (2011) for calculating the $\Delta \mathrm{R}$ values. As mentioned above, samples were ${ }^{14} \mathrm{C}$ dated using LSC, which leads to a reduced number of multiple paired samples from each archaeological context due to the large sample size needed for ${ }^{14} \mathrm{C}$ dating. This handicap made the fulfillment of the methodology proposed by those researchers impossible to follow for many of the dated contexts. Calculation of the $\Delta \mathrm{R}$ values employed the following: a) unrounded ${ }^{14} \mathrm{C}$ ages; b) interpolation between calibration curves IntCal09 and Marine09 (Reimer el al. 2009) for converting the terrestrial biosphere sample ${ }^{14} \mathrm{C}$ age into a marine model age; c) chi-squared test $\left(\chi^{2}: 0.05=T\right)$ as a statistical criterion in the definition of contemporary samples from each group (terrestrial or marine) collected in the same archaeological context (when more than 1 sample was available); and d) establishment of the set of $\Delta \mathrm{R}$ values that can integrate the weighted mean calculation from each coastal region according to the chi-squared test $\left(\chi^{2}: 0.05=T\right)$ results. The $1 \sigma$ error for the $\Delta \mathrm{R}$ determination is obtained by propagation of the errors on the marine age and the modeled marine age from each pair of samples.

We also determine the reservoir age, which is $\mathrm{R}(\mathrm{t})$ defined as the difference between conventional ${ }^{14} \mathrm{C}$ dates from a pair of coeval samples that lived in different carbon reservoirs (Stuiver et al. 1986). 
JM M Martins \& A M M Soares

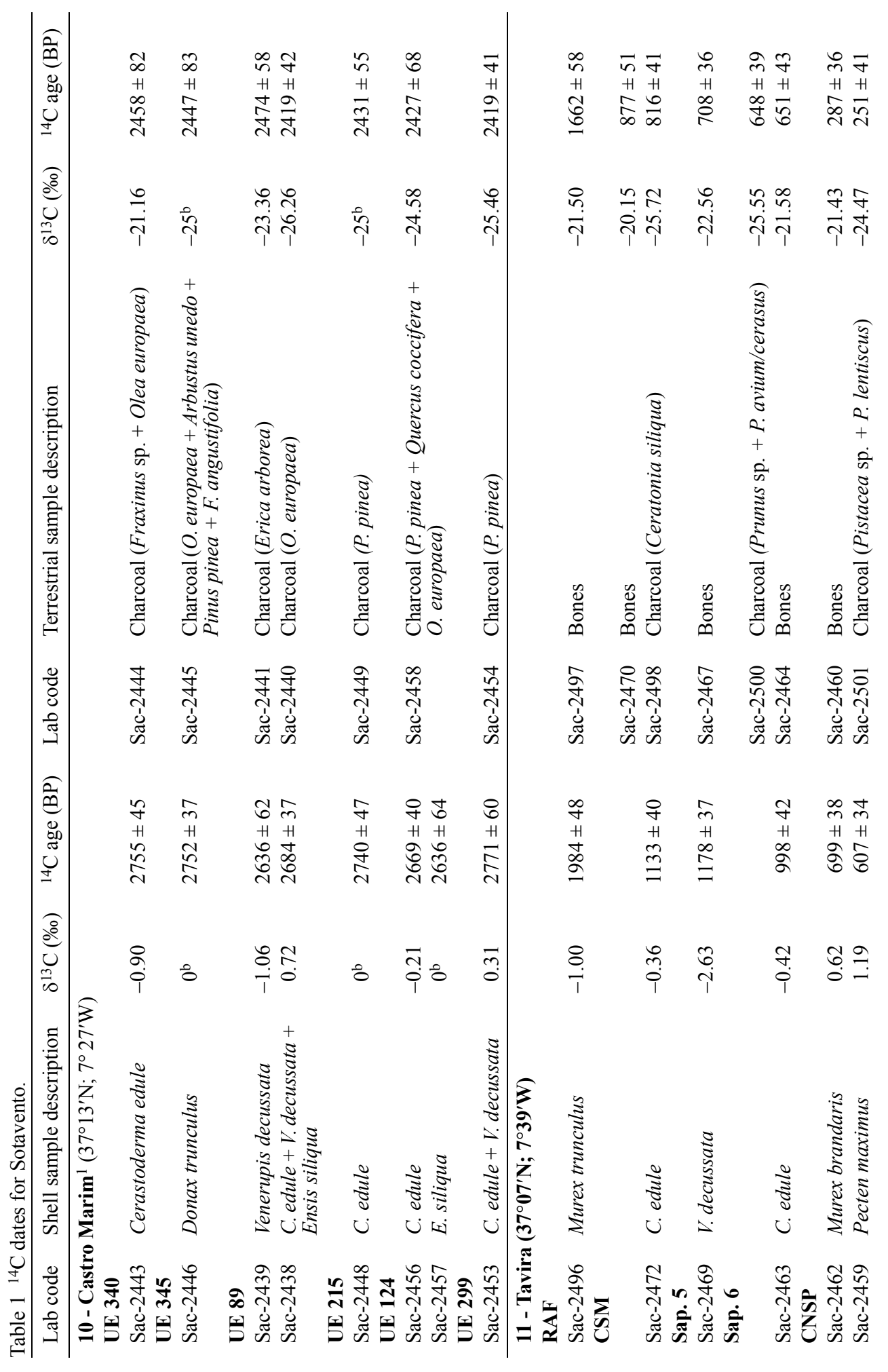




\section{Marine ${ }^{14}$ C Reservoir Effect in S. Atlantic Iberian Coast}

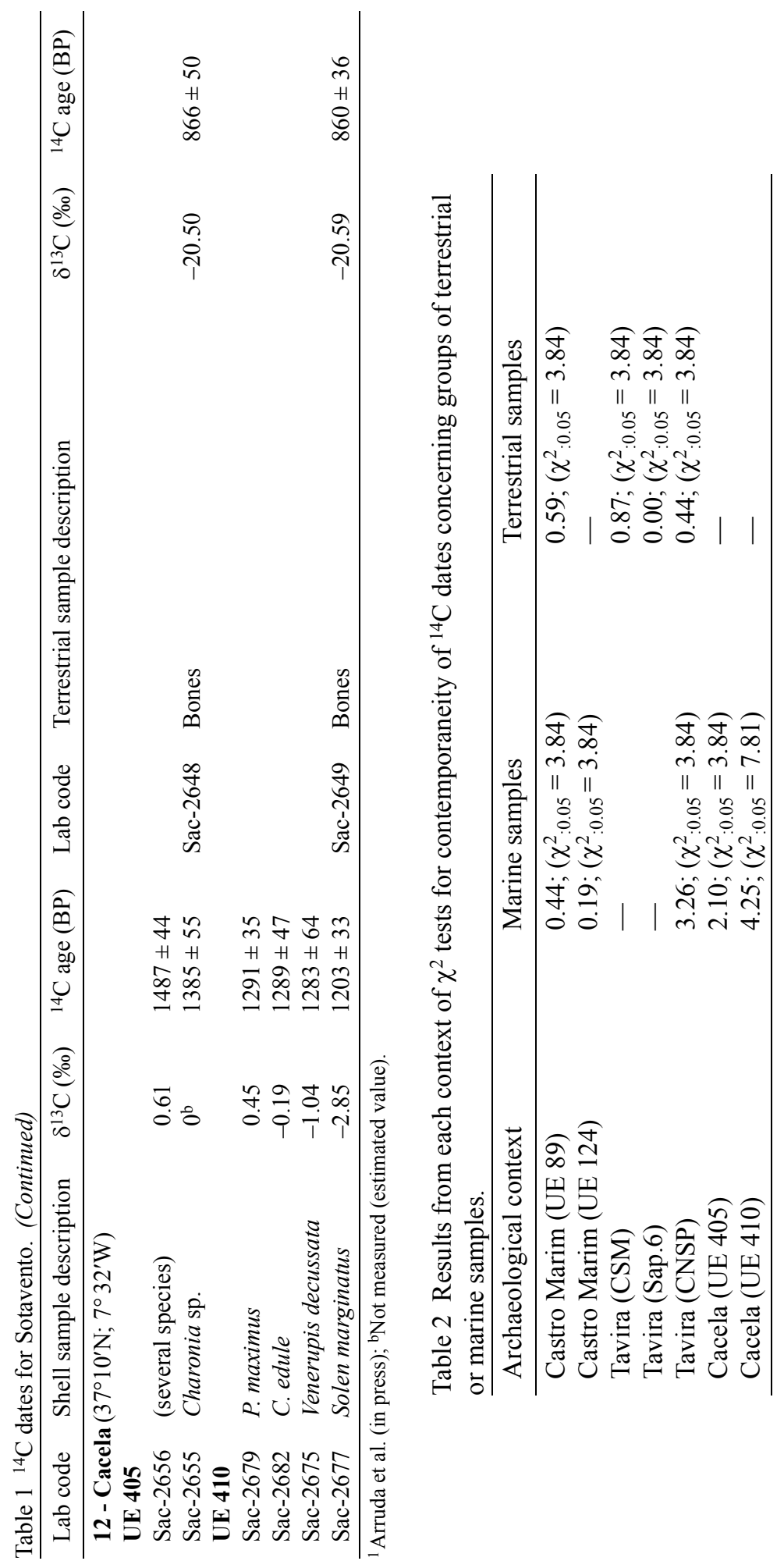




\section{JMM Martins \& A M M Soares}

\section{RESULTS AND DISCUSSION}

${ }^{14} \mathrm{C}$ dates of the terrestrial/marine pairs collected in Sotavento archaeological contexts are listed in Table 1. The use of vegetal remains from long-lived species can lead to a reduced offset between marine and terrestrial ${ }^{14} \mathrm{C}$ ages of a pair, leading to an error in the calculation of the corresponding $\Delta \mathrm{R}$ value. In the data in Table 1, there are 4 cases where besides the dating of a sample of long-lived species a sample of a short-lived species was also dated: Sac-2441, -2440 (Castro Marim UE 89); Sac-2470, -2498 (Tavira CSM); Sac-2500, -2464 (Tavira Sap. 6); Sac-2460, -2501 (Tavira CNSP). The dates determined for each pair are statistically indistinguishable (see Table 2). This leads us to consider that despite the fact that samples Sac-2440, -2498, -2500, and -2501 are from long-lived species, the presence of the "old wood effect" is negligible or insignificant, suggesting a good reliability for the $\Delta \mathrm{R}$ values determined with these samples. In a first approach, therefore, the same can be applied to the data obtained with the other samples of long-lived species from Castro Marim.

For the archaeological contexts where more than 1 sample of the same origin (terrestrial or marine) was collected, a chi-squared test $\left(\chi^{2}: 0.05=T\right)$ was performed. The results obtained with these tests are presented in Table 2, and show that the ${ }^{14} \mathrm{C}$ dates from each archaeological context are statistically indistinguishable, allowing the use of a multipaired sample approach for calculating the $\Delta \mathrm{R}$ from these archaeological contexts.

The results using multi- and single-paired sample approaches are presented in Table 3. Tavira CNSP was one of the archaeological contexts with more samples from different origins ( 2 terrestrial, 2 marine). Four $\Delta \mathrm{R}$ values were calculated, ranging from $-108 \pm 51$ to $+90 \pm 90{ }^{14} \mathrm{C} \mathrm{yr}$, and, consequently, show some variability within the data set. The observed variability should not be ascribed to the nature of the marine biosphere samples but to ${ }^{14} \mathrm{C}$ dates obtained with the terrestrial biosphere samples ( $287 \pm 36$ and $251 \pm 41 \mathrm{BP}$ ), which are encompassed in the last portion of the terrestrial calibration curve. The result is a multiplicity of $\Delta \mathrm{R}$ values in the interpolation performed.

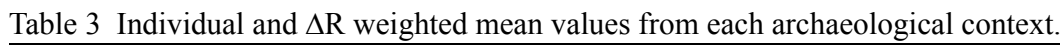

\begin{tabular}{|c|c|c|c|c|c|}
\hline Archaeological context & $\begin{array}{l}\text { Terrestrial } \\
\text { sample }{ }^{14} \mathrm{C} \\
\text { age (BP) }\end{array}$ & $\begin{array}{l}\text { Model } \\
\text { marine }{ }^{14} \mathrm{C} \\
\text { age }(\mathrm{BP})\end{array}$ & $\begin{array}{l}\text { Marine } \\
\text { sample }{ }^{14} \mathrm{C} \\
\text { age (BP) }\end{array}$ & $\begin{array}{l}\Delta \mathrm{R} \\
\left({ }^{14} \mathrm{C} \text { yr }\right)\end{array}$ & $\begin{array}{l}\mathrm{R}(\mathrm{t}) \\
\left({ }^{14} \mathrm{C} \mathrm{yr}\right)\end{array}$ \\
\hline Castro Marim (UE 340) & $2458 \pm 82$ & $2806 \pm 104$ & $2755 \pm 45$ & $-51 \pm 113$ & $297 \pm 94$ \\
\hline Castro Marim (UE 345) & $2447 \pm 83$ & $2789 \pm 90$ & $2752 \pm 37$ & $-\mathbf{3 7} \pm 97$ & $305 \pm 91$ \\
\hline \multirow[t]{5}{*}{ Castro Marim (UE 89) } & $2474 \pm 58$ & $2785 \pm 55$ & $2636 \pm 62$ & $-149 \pm 83$ & $162 \pm 85$ \\
\hline & & & $2684 \pm 37$ & $-101 \pm 66$ & $210 \pm 69$ \\
\hline & $2419 \pm 42$ & $2783 \pm 80$ & $2636 \pm 62$ & $-147 \pm 101$ & $217 \pm 75$ \\
\hline & & & $2684 \pm 37$ & $-99 \pm 88$ & $265 \pm 56$ \\
\hline & \multicolumn{5}{|c|}{$\Delta R$ weighted mean value $=-120 \pm 41{ }^{14} \mathrm{C} \mathrm{yr}$} \\
\hline Castro Marim (UE 215) & $2431 \pm 55$ & $2747 \pm 45$ & $2740 \pm 47$ & $-7 \pm 65$ & $309 \pm 72$ \\
\hline \multirow[t]{3}{*}{ Castro Marim (UE 124) } & $2427 \pm 68$ & $2800 \pm 101$ & $2669 \pm 40$ & $-131 \pm 109$ & $242 \pm 79$ \\
\hline & \multirow{2}{*}{\multicolumn{5}{|c|}{$\Delta R$ weighted mean value $=-146 \pm 81^{14} \mathbf{C ~} \mathbf{~ y r}$}} \\
\hline & & & & & \\
\hline Castro Marim (UE 299) & $2419 \pm 41$ & $2782 \pm 79$ & $2771 \pm 60$ & $-11 \pm 100$ & $352 \pm 73$ \\
\hline Tavira (RAF) & $1662 \pm 58$ & $2028 \pm 59$ & $1984 \pm 48$ & $-44 \pm 76$ & $322 \pm 75$ \\
\hline \multirow[t]{3}{*}{ Cacela (UE 405) } & $866 \pm 50$ & $1251 \pm 50$ & $1487 \pm 44$ & $+236 \pm 67$ & $621 \pm 67$ \\
\hline & & & $1385 \pm 55$ & $+134 \pm 74$ & $519 \pm 74$ \\
\hline & \multicolumn{5}{|c|}{$\Delta \mathrm{R}$ weighted mean value $=+190 \pm 51{ }^{14} \mathrm{C} \mathrm{yr}$} \\
\hline \multirow[t]{5}{*}{ Cacela (UE 410) } & $860 \pm 36$ & $1234 \pm 30$ & $1291 \pm 35$ & $+57 \pm 46$ & $431 \pm 50$ \\
\hline & & & $1289 \pm 47$ & $+55 \pm 56$ & $429 \pm 59$ \\
\hline & & & $1283 \pm 64$ & $+49 \pm 71$ & $423 \pm 73$ \\
\hline & & & $1203 \pm 33$ & $-31 \pm 45$ & $343 \pm 49$ \\
\hline & & & \multicolumn{3}{|c|}{$\Delta R$ weighted mean value $=+26 \pm 26^{14} \mathrm{C} \mathrm{yr}$} \\
\hline
\end{tabular}




\section{Marine ${ }^{14}$ C Reservoir Effect in S. Atlantic Iberian Coast}

Table 3 Individual and $\Delta \mathrm{R}$ weighted mean values from each archaeological context. (Continued)

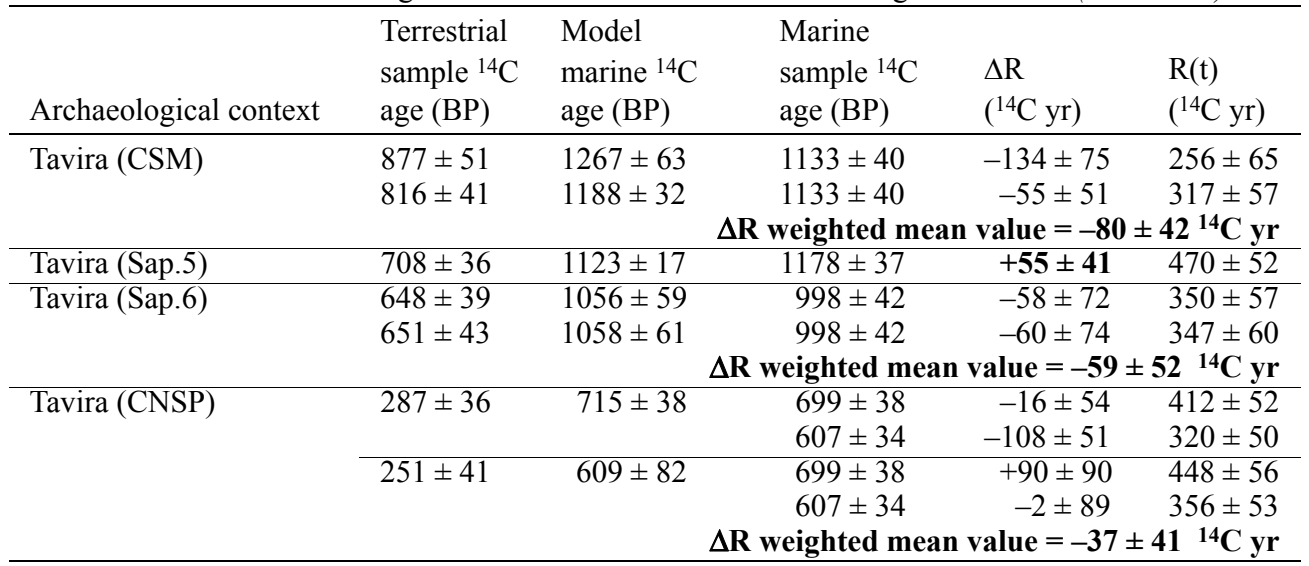

The data from previous research, namely from Barlavento and Andalusian coasts (Soares and Martins 2009, 2010) was recalculated according to the methodology mentioned above and used for the Sotavento coast. This approach was made in order to harmonize all the results for the southern Iberian Atlantic coast that are presented in Table 4. Calendar dates from each archaeological context were obtained using the respective conventional ${ }^{14} \mathrm{C}$ date (or weighted mean) determined with the terrestrial sample (or terrestrial samples), the calibration curve IntCal09 (Reimer et al. 2009) and the calibration program OxCal v 4.1 (Bronk Ramsey 2009).

Table $4 \Delta \mathrm{R}$ values for the 3 regions of the southern Iberian Atlantic coast (Barlavento, Sotavento, and Andalusia).

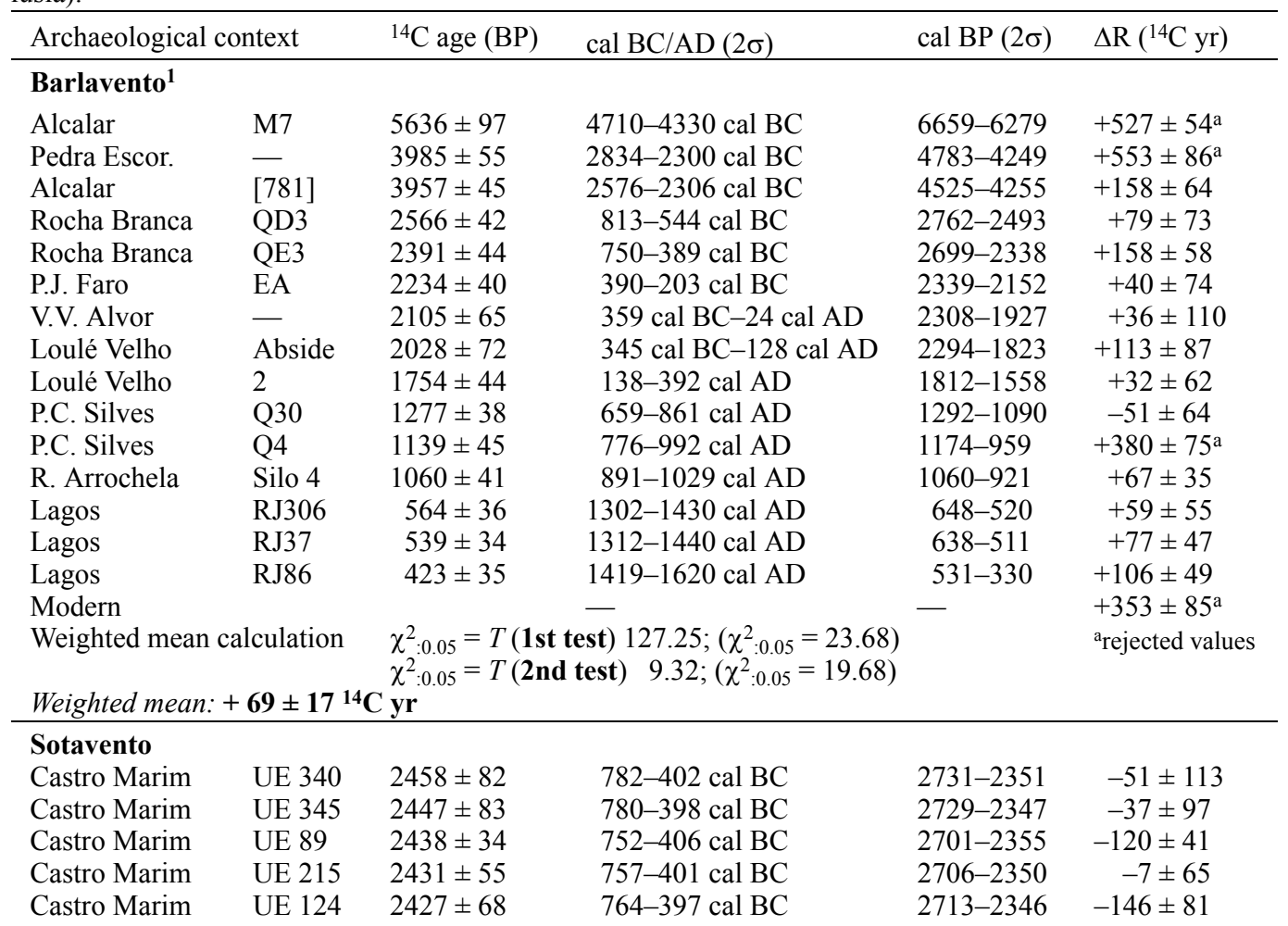




\section{J M M Martins \& A M M Soares}

Table $4 \Delta \mathrm{R}$ values for the 3 regions of the southern Iberian Atlantic coast (Barlavento, Sotavento, and Andalusia). (Continued)

\begin{tabular}{|c|c|c|c|c|c|}
\hline \multicolumn{2}{|c|}{ Archaeological context } & \multirow{2}{*}{$\frac{{ }^{14} \mathrm{C} \text { age }(\mathrm{BP})}{2419 \pm 41}$} & \multirow{2}{*}{$\frac{\mathrm{cal} \mathrm{BC} / \mathrm{AD}(2 \sigma)}{752-399 \mathrm{cal} \mathrm{BC}}$} & \multirow{2}{*}{$\frac{\text { cal BP }(2 \sigma)}{2701-2348}$} & \multirow{2}{*}{$\frac{\Delta \mathrm{R}\left({ }^{14} \mathrm{C} \mathrm{yr}\right)}{-11 \pm 100}$} \\
\hline Castro Marim & UE 299 & & & & \\
\hline Tavira & RAF & $1662 \pm 58$ & $252-536 \mathrm{cal} A D$ & $1669-1415$ & $-44 \pm 76$ \\
\hline Cacela & UE 405 & $866 \pm 50$ & $1040-1260 \mathrm{cal} \mathrm{AD}$ & $910-690$ & $+190 \pm 51^{b}$ \\
\hline Cacela & UE 410 & $860 \pm 36$ & $1046-1260 \mathrm{cal} \mathrm{AD}$ & $905-690$ & $+26 \pm 26$ \\
\hline Tavira & CSM & $839 \pm 32$ & $1057-1265 \mathrm{cal} \mathrm{AD}$ & $893-685$ & $-80 \pm 42$ \\
\hline Tavira & Sap.5 & $708 \pm 36$ & $1227-1389 \mathrm{cal} \mathrm{AD}$ & $723-562$ & $+55 \pm 41$ \\
\hline Tavira & Sap.6 & $649 \pm 29$ & $1281-1395 \mathrm{cal} \mathrm{AD}$ & $670-556$ & $-59 \pm 52$ \\
\hline Tavira & CNSP & $271 \pm 27$ & $1520-1797$ cal AD & $430-153$ & $-37 \pm 32$ \\
\hline \multicolumn{2}{|c|}{$\begin{array}{l}\text { Modern } \\
\text { Weighted mean calculation }\end{array}$} & & - & - & $+17 \pm 52$ \\
\hline Weighted mear & ilculation & \multicolumn{3}{|c|}{$\begin{array}{l}\chi^{2}: 0.05=T(\text { 1st test }) 34.59 ;\left(\chi^{2}: 0.05=21.03\right) \\
\chi^{2}: 0.05=T(2 \text { nd test }) 17.75 ;\left(\chi^{2}: 0.05=19.68\right)\end{array}$} & ${ }^{b}$ rejected value \\
\hline \multicolumn{6}{|c|}{ Andalusian coast ${ }^{\mathbf{1}}$} \\
\hline Papa Uvas & E15 & $4574 \pm 108$ & $3632-2942$ cal BC & $5581-4891$ & $-117 \pm 114^{\mathrm{c}}$ \\
\hline Papa Uvas & FIV & $4475 \pm 49$ & $3357-2945$ cal BC & $5306-4894$ & $-103 \pm 80^{c}$ \\
\hline La Viña & Silo 16 & $4428 \pm 83$ & 3345-2911 cal BC & $5294-4860$ & $+200 \pm 66^{\mathrm{d}}$ \\
\hline Papa Uvas & F12 & $4421 \pm 94$ & 3355-2898 cal BC & $5304-4847$ & $+98 \pm 106^{d}$ \\
\hline Papa Uvas & B10 & $4054 \pm 195$ & $3308-2027 \mathrm{cal} \mathrm{BC}$ & $5257-3976$ & $+327 \pm 233^{d}$ \\
\hline Niebla & UE69 & $2067 \pm 65$ & $351 \mathrm{cal} \mathrm{BC}-71 \mathrm{cal} \mathrm{AD}$ & $2300-1880$ & $-163 \pm 105^{c}$ \\
\hline El Eucaliptal & UE 4 & $1751 \pm 84$ & 73-530 cal AD & $1877-1421$ & $-142 \pm 73^{\mathrm{c}}$ \\
\hline Niebla & UE16 & $904 \pm 40$ & $1033-1213 \mathrm{cal} \mathrm{AD}$ & $917-737$ & $-82 \pm 77^{\mathrm{c}}$ \\
\hline Niebla & SA & $218 \pm 43$ & $1524-1955$ cal AD & $427-0$ & $-88 \pm 54^{c}$ \\
\hline \multicolumn{6}{|c|}{ Weighted mean calculation ( ${ }^{\mathrm{c}}$ negative $\Delta \mathrm{R}$ values) $0.75 ;\left(\chi^{2}: 0.05=11.07\right)$} \\
\hline \multicolumn{6}{|c|}{ Weighted mean: $-\mathbf{1 0 8} \pm \mathbf{3 1}{ }^{14} \mathbf{C} \mathbf{y r}$} \\
\hline \multicolumn{6}{|c|}{ Weighted mean calculation ( ${ }^{\mathrm{d}}$ positive $\Delta \mathrm{R}$ values) $1.09 ;\left(\chi^{2}: 0.05=5.99\right)$} \\
\hline Weighted mean & $180 \pm 66$ & Cyr & & & \\
\hline
\end{tabular}

Fifteen $\Delta \mathrm{R}$ values were determined for the Barlavento coast, but $3(+527 \pm 54,+553 \pm 86$, and $+380 \pm 75{ }^{14} \mathrm{C} \mathrm{yr}$ ) were rejected in the calculation of the $\Delta \mathrm{R}$ weighted mean value due to their $\chi^{2}$ results $\left(127.25 ;\left(\chi^{2}: 0.05=23.68\right)\right)$. With the remaining 12 values, a $\Delta R$ weighted mean value of $+69 \pm$ $17{ }^{14} \mathrm{C}$ yr was determined for this coastal region. For the Sotavento region, $13 \Delta \mathrm{R}$ values were obtained but $1\left(+190 \pm 51{ }^{14} \mathrm{C}\right.$ yr) was rejected; the remaining 12 values were statistically indistinguishable $\left(17.75 ;\left(\chi^{2}: 0.05=19.68\right)\right)$. A $\Delta \mathrm{R}$ weighted mean value of $-26 \pm 14{ }^{14} \mathrm{C}$ yr was thereby obtained for the Sotavento coastal region.

For the Andalusian coast, $2 \Delta \mathrm{R}$ weighted mean values were obtained. Two sets of $\Delta \mathrm{R}$ values were considered in the calculation of the weighted mean value, namely the 3 positive values $(+200 \pm 66$, $+98 \pm 106$, and $+327 \pm 233{ }^{14} \mathrm{C} \mathrm{yr}$ ) resulting in a $\Delta \mathrm{R}$ weighted mean value of $+180 \pm 66{ }^{14} \mathrm{C} \mathrm{yr}$, and the remaining 6 negative values with a $\Delta \mathrm{R}$ weighted mean value of $-108 \pm 31{ }^{14} \mathrm{C} \mathrm{yr}$. It must be noted that the $\Delta \mathrm{R}$ weighted mean values obtained in previous research (Soares and Martins 2009, 2010) for the Barlavento coast $\left(\Delta \mathrm{R}=+65 \pm 20{ }^{14} \mathrm{C}\right.$ yr $)$ and the Andalusian coast $\left(\Delta \mathrm{R}=-135 \pm 20{ }^{14} \mathrm{C}\right.$ yr $)$ are not significantly different from the values determined in this study. The pairs of samples used in both studies for calculation of the $\Delta \mathrm{R}$ weighted mean values (Barlavento and Andalusian coasts) are the same, with the observed small differences ascribed to the use of different calculation methods.

If the $\Delta \mathrm{R}$ data given in Table 4 are plotted against time (Figure 2), the variability of the $\Delta \mathrm{R}$ can be observed and compared among the 3 coastal regions. The positive $\Delta \mathrm{R}$ values can be correlated with the presence of upwelling, while low or negative $\Delta \mathrm{R}$ values correspond to weak, or even nonexistent, upwelling. 
Marine ${ }^{14}$ C Reservoir Effect in S. Atlantic Iberian Coast

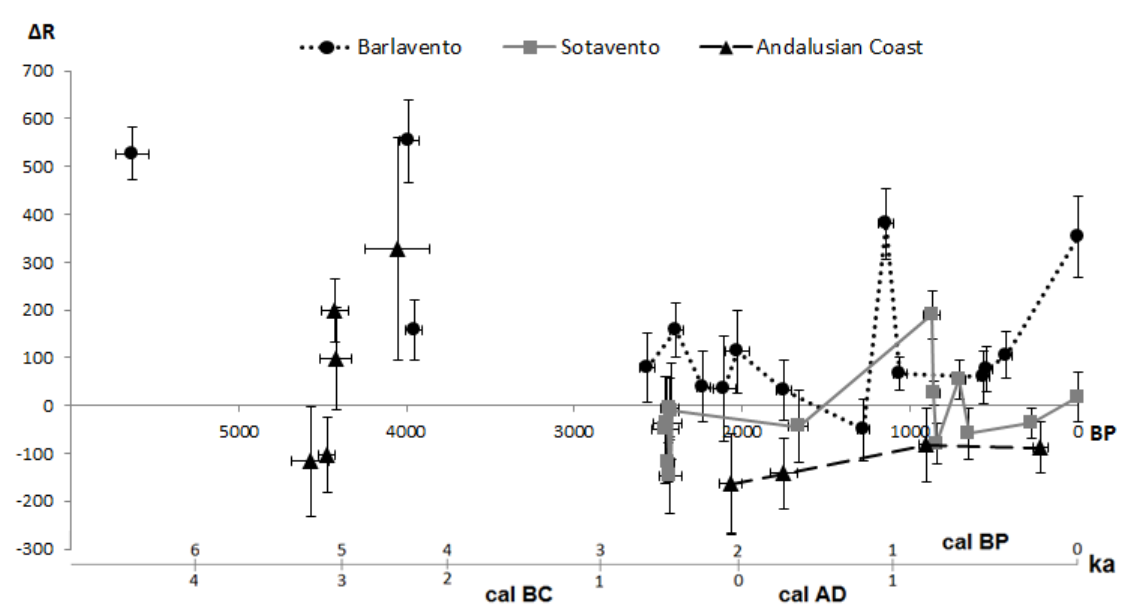

Figure 2 Marine ${ }^{14} \mathrm{C}$ reservoir effect for the 3 coastal regions. $\Delta \mathrm{R}( \pm 1 \sigma)$ values are plotted versus terrestrial ${ }^{14} \mathrm{C}$ ages $( \pm 1 \sigma)$.

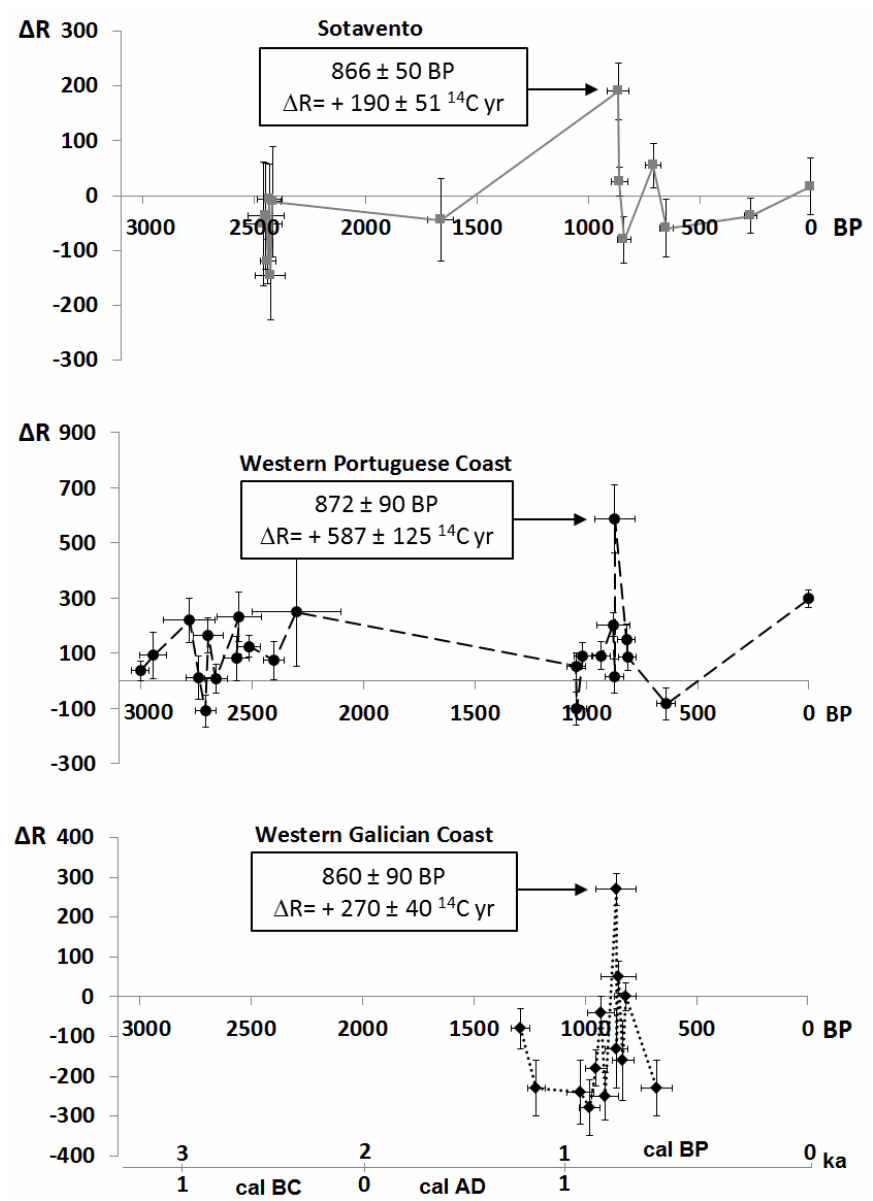

Figure 3 The synchronous peaks around $870 \mathrm{BP}$ 


\section{JMM Martins \& A M M Soares}

The Barlavento coast has the higher $\Delta \mathrm{R}$ values, the Andalusian coast the more negative ones, and the Sotavento coast has values between these two. As mentioned above, the Sotavento coast can be considered a transition zone between an area (the Barlavento coast) highly influenced by prolongation of the western coastal upwelling system into the southern Portuguese coast and an area where the upwelling regime is absent (the Andalusian coast). The $\Delta \mathrm{R}$ values that determined for the 3 regions are in accordance with the prevailing oceanographic conditions. However, it must be noted that before $3 \mathrm{ka} \mathrm{BP}$, positive $\Delta \mathrm{R}$ values were determined for the Andalusian coast and highly positive values for the Barlavento coast, strongly suggesting a major change in the oceanographic conditions prevailing in the entire region of the southern Iberian Atlantic coast (see rejected values in calculation of $\Delta \mathrm{R}$ weighted mean for the Barlavento region), as already seen in previous research (Soares and Dias 2006b; Soares and Martins 2010). A similar situation has been verified in 2 periods between the Last Glacial Maximum and the Holocene, which can be explained by the extension of the Azores Front eastward along the Azores Current into the Gulf of Cadiz (Rogerson et al. 2004). If we take into account that a strong upwelling is always associated with the Azores Front, the positive $\Delta \mathrm{R}$ values that were determined for the time period in question can be easily explained.

Moreover, at $866 \pm 50 \mathrm{BP}$, a peak $\left(\Delta \mathrm{R}=+190 \pm 51{ }^{14} \mathrm{C}\right.$ yr $)$ in the $\Delta \mathrm{R}$ data set from the Sotavento coast was obtained, which matches another peak $\left(\Delta \mathrm{R}=+587 \pm 125{ }^{14} \mathrm{C}\right.$ yr $)$ obtained at $872 \pm 90 \mathrm{BP}$ in the western Portuguese coast (Soares and Dias 2006a) and another $\left(\Delta \mathrm{R}=+270 \pm 40{ }^{14} \mathrm{C}\right.$ yr) obtained at $860 \pm 90 \mathrm{BP}$ in the western Galician coast (Soares and Dias 2007). These synchronous peaks (see Figure 3) can be related with the cold event at $0.8 \mathrm{ka}$ cal BP (deMenocal et al. 2000), which in turn can be related with the climatic reorganization associated with the end of the Medieval Warm Period and the beginning of the Little Ice Age.

\section{CONCLUSIONS}

A record of past reservoir ages is preserved in the contemporary marine and terrestrial material, which can provide valuable information on the intensity of coastal upwelling and paleoenvironmental processes in marine regions influenced by this phenomenon. We built on the previous research of $\Delta \mathrm{R}$ in the southern Atlantic Iberian coast, adding new $\Delta \mathrm{R}$ values for the Sotavento coastal region, an area not yet analyzed. At the same time, using a new calculation approach, $\Delta \mathrm{R}$ weighted mean values were recalculated for the Barlavento and Andalusian coasts. The results for the last $3000 \mathrm{yr}(\Delta \mathrm{R}$ $=+69 \pm 17{ }^{14} \mathrm{C}$ yr, Barlavento coast; $\Delta \mathrm{R}=-26 \pm 14{ }^{14} \mathrm{C}$ yr, Sotavento coast; $\Delta \mathrm{R}=-108 \pm 31{ }^{14} \mathrm{C} \mathrm{yr}$, Andalusian coast) are in accordance with the oceanographic conditions present in each area.

On the other hand, a peak in the $\Delta \mathrm{R}$ data set for the Sotavento coast was identified at $866 \pm 50 \mathrm{BP}$, which can be related to the Bond event of $0.8 \mathrm{ka}$ cal BP. Finally, the obtained data suggests that very different oceanographic conditions (high positive $\Delta \mathrm{R}$ values) prevail in the Barlavento and Andalusian coastal areas and, consequently, in all the northern Gulf of Cadiz region during the 5th millennium cal BP, perhaps due to the extension of the Azores Front eastward along the Azores Current penetrating into the Gulf of Cadiz.

\section{ACKNOWLEDGMENTS}

This work was partially supported by the Portuguese Science and Technology Foundation (FCTMCTES) research project PTDC/MAR/68932/2006: "The Ocean Reservoir Effect in the transition areas of the West-Iberian coastal Upwelling (Aveiro/Mouth of the River Minho; Cape Santa Maria/ Mouth of the River Guadiana)." J Martins acknowledges the PhD grant SFRH/BD/45528/2008 from the same institution and the travel grant from the Organizing Committee of the 21st International Radiocarbon Conference. 


\section{Marine ${ }^{14}$ C Reservoir Effect in S. Atlantic Iberian Coast}

\section{REFERENCES}

Arruda AM, Soares AMM, Freitas VT, Oliveira CF, Martins JMM, Portela PC. In press. A cronologia relativa e absoluta da ocupação Sidérica do Castelo e Castro Marim. XELB 12. In Portuguese.

Ascough PL, Cook, GT, Dugmore AJ. 2005. Methodological approaches to determining the marine radiocarbon reservoir effect. Progress in Physical Geography 29(4):532-47.

Ascough PL, Cook GT, Dugmore AJ, Scott EM. 2007. The North Atlantic marine reservoir effect in the Early Holocene: implications for defining and understanding MRE values. Nuclear Instruments and Methods in Physics B 259(1):438-47.

Ascough PL, Cook GT, Dugmore AJ. 2009. North Atlantic marine ${ }^{14} \mathrm{C}$ reservoir effects: implications for lateHolocene chronological studies. Quaternary Geochronology 4(3):171-80.

Bronk Ramsey C. 2009. Bayesian analysis of radiocarbon dates. Radiocarbon 51(1):337-60.

deMenocal PB, Ortiz J, Guilderson T, Sarnthein M. 2000. Coherent high- and low-latitude climate variability during the Holocene warm period. Science 288(5474): 2198-202.

Diffenbaugh NS, Sloan LC, Snyder MA. 2003. Orbital suppression of wind-driven upwelling in the California Current at 6 ka. Paleoceanography 18:1051, doi: 10.1029/2002PA000865.

Ferreira DB. 1984. Le Systeme Climatique de 1'Upwelling Ouest Iberique. [Report \#19 of the Linha de Acção de Geografia Física]. Lisbon: Centro de Estudos Geográficos. INIC. 92 p.

Fiúza AFG. 1982. The Portuguese coastal upwelling system. In: Actual Problems of Oceanography in Portu$\mathrm{gal}$. Lisbon: Junta Nacional de Investigação Científica e Tecnológica. p 45-71.

Fiúza AFG. 1983. Upwelling patterns off Portugal. In: Suess E, Thiede J, editors. Coastal Upwelling. Its Sediment Record. New York: Plenum. p 85-98.

Fiúza AFG, Macedo ME, Guerreiro MR. 1982. Climatological space and time variation of the Portuguese coastal upwelling. Oceanologica Acta 5:31-40.

Ingram BL. 1998. Differences in radiocarbon age between shell and charcoal from a Holocene shellmound in northern California. Quaternary Research 49(1): $102-10$.

Kennett DJ, Ingram BL, Erlandson JM, Walker P. 1997. Evidence for temporal fluctuations in marine radiocarbon reservoir ages in the Santa Barbara Channel, southern California. Journal of Archaeological Science 24(11):1051-9.

Martins JMM, Martín AM, Portela PJC, Soares AMM. 2012. Improving the ${ }^{14} \mathrm{C}$ dating of marine shells from the Canary Islands for constructing more reliable and accurate chronologies. Radiocarbon 54(3-4):943-52.

Reimer PJ, McCormac G, Moore J, McCormick F, Murray EV. 2002. Marine radiocarbon reservoir correc- tions for the mid- to late Holocene in the eastern subpolar North Atlantic. The Holocene 12(2):129-35.

Reimer PJ, Baillie MGL, Bard E, Bayliss A, Beck JW, Blackwell PG, Bronk Ramsey C, Buck CE, Burr GS, Edwards RL, Friedrich M, Grootes PM, Guilderson TP, Hajdas I, Heaton T, Hogg AG, Hughen KA, Kaiser KF, Kromer B, McCormac FG, Manning SW, Reimer RW, Richards DA, Southon JR, Talamo S, Turney CSM, van der Plicht J, Weyhenmeyer CE. 2009. IntCa109 and Marine09 radiocarbon age calibration curves, 0-50,000 years cal BP. Radiocarbon 51(4): 1111-50.

Rogerson M, Rohling EJ, Weaver PPE, Murray JW. 2004. The Azores Front since the Last Glacial Maximum. Earth and Planetary Science Letters 222(3-4): 779-89.

Russell N, Cook GT, Ascough PL, Scott EM, Dugmore AJ. 2011. Examining the inherent variability in $\Delta R$ : new methods of presenting $\Delta \mathrm{R}$ values and implications for MRE studies. Radiocarbon 53(2):277-88.

Soares AMM. 1989. O Efeito de Reservatório Oceânico nas Águas Costeiras de Portugal Continental. Sacavém: Instituto de Ciências e Engenharia Nucleares. Instituto Nacional de Engenharia e Tecnologia Industrial. 135 p. In Portuguese.

Soares AMM. 1993. The ${ }^{14} \mathrm{C}$ content of marine shells: evidence for variability in coastal upwelling off Portugal during the Holocene. In: Isotope Techniques in the Study of Past and Current Environmental Changes in the Hydrosphere and the Atmosphere. Vienna: IAEA. p 471-85.

Soares AMM. 2005. Variabilidade do "Upwelling" Costeiro durante o Holocénico nas Margens Atlânticas Ocidental e Meridional da Península Ibérica [PhD dissertation]. Faro: Faculdade de Ciências do Mar e do Ambiente, Universidade do Algarve. In Portuguese.

Soares AMM. 2010. Comment on "Formation of chenier plain of the Doñana marshland (SW Spain): Observations and geomorphic model" by A. RodríguezRamírez and C.M. Yáñez-Camacho. [Marine Geology 254 (2008) 187-196]. Marine Geology 275(1-4): 287-89.

Soares AMM, Dias JMA. 2006a. Coastal upwelling and radiocarbon-evidence for temporal fluctuations in ocean reservoir effect off Portugal during the Holocene. Radiocarbon 48(1):45-60.

Soares AMM, Dias JMA. 2006b. Once upon a time...the Azores Front penetrated into the Gulf of Cadiz. In: Proceedings of the 5th Symposium on the Iberian Atlantic Margin. Aveiro: Universidade de Aveiro. p 205-6.

Soares AMM, Dias JMA. 2007. Reservoir effect of coastal waters off western and northwestern Galicia. Radiocarbon 49(2):925-36.

Soares AMM, Martins JMM. 2009. Radiocarbon dating of marine shell samples. The marine radiocarbon res- 


\section{J M M Martins \& A M M Soares}

ervoir effect of coastal waters off Atlantic Iberia during Late Neolithic and Chalcolithic periods. Journal of Archaeological Science 36(12):2875-81.

Soares AMM, Martins JMM. 2010. Radiocarbon dating of marine samples from Gulf of Cadiz: the reservoir effect. Quaternary International 221(1-2):9-12.

Stuiver M, Braziunas TF. 1993. Modeling atmospheric ${ }^{14} \mathrm{C}$ influences and ${ }^{14} \mathrm{C}$ ages of marine samples to 10,000 BC. Radiocarbon 35(1):137-89.
Stuiver M, Polach HA. 1977. Discussion: reporting of ${ }^{14} \mathrm{C}$ data. Radiocarbon 19(3):355-63.

Stuiver M, Pearson GW, Braziunas T. 1986. Radiocarbon age calibration of marine samples back to $9000 \mathrm{cal} \mathrm{yr}$ BP. Radiocarbon 28(2B):980-1021.

Vargas JM, García-Lafuente J, Delgado J, Criado F. 2003. Seasonal and wind-induced variability of sea surface temperature patterns in the Gulf of Cádiz. Journal of Marine Systems 38:205-19. 